\title{
Management of Pyricularia grisea, the Rice Blast Pathogen through Botanical Pesticides
}

\author{
Shafaullah $^{1}$, M. Aslam Khan ${ }^{2}$ \\ ${ }^{1,2}$ Department of Plant Pathology, University of Agriculture Faisalabad, 3800 Pakistan
}

\begin{abstract}
Rice blast, caused by Pyricularia grisea contributes a major decline in rice production. The unnecessary use of many synthetic fungicides causes deleterious and lethal ecological effects. To cope with these fatal side effects of fungicides various alternative means are optimized in different countries of the world. As a result of this great concern, utilization of higher plants products as innovative chemotherapeutic agents in plant protection is increasing day by day. In present study different type of plant extracts were used to manage leaf and neck blast of rice in arid climate of Sheikhupura, Punjab Pakistan. The consecutive trails of seven days intervals were conducted using different plant extracts. Two years experimental data revealed that ginger and garlic extracts after 21 days exhibited promising result of eliminating leaf blast severity to $9.82 \%$ and $9.89 \%$ respectively, whereas a significant reduction of $14.18 \%$ and $13.97 \%$ was observed in neck blast by applying these plant extracts as compared to control. After $3^{\text {rd }}$ week of Chili extract application, chili was proved best botanical pesticide against rice neck blast, whereas onion and garlic extract showed equal efficacy on eliminating neck blast. Eucalyptus was found least effect on leaf and neck blast, more over aggressive disease was observed in year 2010 than 2011.
\end{abstract}

Keywords: Pyricularia grisea, Rice, Plant Protection, Botanical Pesticides

\section{Introduction}

Rice (Oryza sativa L.) being the most essential cereal is consumed by $50 \%$ world's population, According to Food and Agricultural Organization it is a staple food providing 2400 calories per day that is the least food safety required of a person per day[1-2]. Unfortunately this crop is more susceptible to several diseases, the most significant is rice blast caused by Pyricularia grisea reported in 85 countries [3]. This pathogen brings about severe damage to crop some time up to $100 \%$. In Philippine during 1983, 50-85\% yield losses were reported, In Korea and China losses were $8 \%$ and $14 \%$ respectively, whereas minimum losses was noted in India during 1960-1961 only 5-10\% crop was effected by rice blast[4-5-6]. Most of the basmati varieties cultivated in Pakistan are prone to rice blast. In Pakistan rice blast is mostly found in all the rice growing areas including district Lahore, Gujranwala, Sheikhupura, Hafizabad, Sialkot, Narowal, Toba Tek Sing, Vehari and Gaggo Mandi[7].Usually fungicide are found suitable in controlling rice diseases however they prove very poisonous to friendly organism and become source of environment destruction [89].Therefore, it is need of time to use other sources like plant products as controlling agent of Pyricularia grisea for human and environmental protection. Among these plant products having antifungal quality are neem, ginger, garlic, datura, onion, turmeric, chili, eucalyptus etc. Disease management through seed treatment as a fundamental factor of rice crop production to avoid undesirable crop losses. [10].The fungal pathogens of rice, Sarocladium oryzae (sheath rot pathogen) and Pyricularia oryzae (blast pathogen), were effectively controlled by neem oil and neem seed kernel extracts [11]. Choi et al in 2004 used plant products as fungicides and found roots of Chloranthus japonica and stem of Paulownia coreana were effective in the management of rice blast they also noted that treatments with P.guineense and Carbendazim had comparable leaf blast suppression effects [12]. In another study, garlic extract more effective as an alternative to conventional chemical fungicide in the management of rice blast disease [13]. In the view of agricultural pest management, botanical pesticides are best applicable practice in organic food production in technologically advanced countries but can play broad role in the production and post-harvest protection of foodstuff crops in emerging states.

\section{Material and Method}

The trial was conducted in the Rice Research Institute Kala Shah Kaku, Sheikhupura, Punjab, Pakistan, during khraif season 2010 and 2011.Rice nursery of highly susceptible cultivar Basmati C-622 was sown in the month of May. Seeds were first dipped in the drum containing salt solution [7-14]. Unhealthy or weak seeds started flowing the uppermost was removed. Then the healthy seeds were collected from the drum and kept in cool and dry place in the form of lots on gunny bags and irrigated with the help of sprinkler. The germinated seeds were prepared for seeding after two days. Paddling method was used for preparation of land. At beginning, one plough followed by three cultivations and two planking was done. After one week, one plough, two cultivations and two planking was done for the homogenously fertile land. The plot size was 2 x 6 meters and Plant to plant distance was 9" while row to row distance was 18".The NPK@ 100:50:0 as fertilizer, Padan@9 kg/ acre as an insecticides and Michate (a) $800 \mathrm{ml} /$ acre as a weedicide were used. The trial was laid in RCBD with four replications. Three applications of botanical pesticides at weekly intermission were given [715]. The plant extracts used as botanical pesticides were enlisted in table 1. Botanical pesticides were made by preparing standard plant extracts solution (100\%). For this purpose 20 grams leaf/bulb extract of each plant were thoroughly washed with tap water followed by distilled water and dissolved in $20 \mathrm{ml}$ distilled (@) one gram of tissue in one $\mathrm{ml}$ of water $1: 1 \mathrm{w} / \mathrm{v}$ ) and sieved through doubled layered cheese cloth[16].The leaf/bulb/rhizome extract @ $20 \mathrm{ml} /$ litter were applied as foliar spray. The plots were 


\section{International Journal of Science and Research (IJSR) \\ ISSN (Online): 2319-7064 \\ Index Copernicus Value (2013): 6.14 | Impact Factor (2014): 5.611}

given three sprays at an interval of seven days and water was sprayed as a control. Every treatment was replicated thrice. The data on leaf and neck blast severity were collected using the typical visual symptoms of disease ratings scale 0-9 developed by International Rice Research Institute. [17] Interpretation of scale is described in table 2.

Table 1: Plants used as botanical pesticides

\begin{tabular}{|c|c|c|c|c|}
\hline Sr. No. & Plant & Scientific Name & Parts used & Preparations \\
\hline 1 & Ginger & Zingiberofficinale Rose & Rhizome & Crude extract \\
2 & Garlic & Allium sativum & Bulb, Leaf & Crude extract \\
3 & Datura & Daturastamonium & Leaf, Stem & Crude extract \\
4 & Onion & Allium cepa & Rulb & Crude extract \\
5 & Turmeric & Curcuma longa & Leaf & Crude extract \\
6 & Chilli & Capsicum annum & Ceaftract \\
7 & Aak & Calotropisprocera & Leaf & Crude extract \\
8 & Neem & Azodirachtaindica & Leaf & Crude extract \\
\hline
\end{tabular}

Table 2: Disease rating scale for leaf and neck blast

\begin{tabular}{l}
\hline Disease rating scale for leaf blast \\
\hline 0= No of lesions. \\
$1=$ Small brown speaks of pin point size or large brown speak \\
= without speculating center. \\
$2=$ Small round dish to slightly elongated necrotic grey spots \\
about $1-2$ (mm) in diameter with distinct brown margin lesions \\
are mostly found on lower leaves. \\
$3=$ Lesion type is same in Scale 2, but significant number of \\
lesion are one on upper leaves. \\
$4=$ Typical susceptible blast lesion, 3 mm or longer infecting \\
lesions than $2 \%$ of leaf area. \\
$5=$ Typical blast lesion infecting $2-10 \%$ of the leaf area. \\
$6=$ Typical blast lesion infecting $11-25 \%$ of the leaf area. \\
$7=$ Typical blast lesion infecting $26-50 \%$ of the leaf area. \\
$8=$ Typical blast lesion infecting $51-75 \%$ of the leaf area many \\
leaves are dead \\
$9=$ More than $75 \%$ leaf are affected
\end{tabular}

$0=$ No visible lesions on only few pedicles

$1=$ Lesion on several pedicels or secondary branches.

$3=$ Lesions on few primary branches or middle panicle axis branches

$5=$ Lesion partially around panicle base (node) or upper most internode or low part of panicle axis near the base

$7=$ Lesion completely around panicle base or upper most internode or panicle axis near the base with less than $30 \%$ of filled grain

\section{Disease $\%=\frac{\text { Average no. of disease plant observed }}{\mathrm{N}(\text { Scale rea ding) }} \times 100$}

\section{Results}

Leaf Blast: Efficacy of different Botanical pesticides on leaf and neck blast under field conditions is given in the table 3 and 4. Among all of botanical pesticides used against leaf blast, ginger and garlic revealed best result after one week aak, onion, chili and neem showed intermediate results whereas eucalyptus was found least effective in controlling leaf blast disease. Similar results were observed after $2^{\text {nd }}$ week application where ginger and garlic remained more effective against leaf blast. Aak, onion, chili and neem exhibited intermediate effectiveness. Ginger as botanical pesticide exhibited promising results in eliminating disease severity to $9.82 \%$ whereas garlic control $9.89 \%$ after 21 days. In control where water was sprayed, disease was found at its full tune $(51.37 \%)$ after 21 days. Significant disease was observed during 2010 than 2011. The interaction of day, year and treatment was significant at $P=0.05$.

Neck blast: In case of neck blast, chili and aak was found most effective throughout first week of spray at pinnacle phase. Whereas, garlic, onion, ginger and turmeric displayed intermediate results. In second week, botanical pesticides application to control neck blast, chili and aak were more efficient of all botanical pesticides used. On the other hand, garlic, onion, ginger and turmeric were statistically at par with each other. In third week of spray, disease percentage was recorded $10.95 \%$ and $11.93 \%$ by the chili and aak respectively. Garlic, onion, ginger and turmeric showed intermediate response with $13.91 \%, 13.91 \%, 14.18 \%$ and $14.46 \%$ disease exhibition respectively. Similar to leaf blast eucalyptus was again prove minimum effectiveness in reducing the rice neck blast $(28.47 \%, 30.59 \%$ and $34.30 \%$ in 7,14 and 21 days respectively). The control (water) sprayed maximize the disease $(45.87 \%)$. The effect of days and years were significant at $\mathrm{P}=0.05$. The interaction of day year and treatment was significant at $\mathrm{P}=0.05$. Significantly higher disease was observed during the year 2010 than 2011. 


\section{International Journal of Science and Research (IJSR) ISSN (Online): 2319-7064 \\ Index Copernicus Value (2013): 6.14 | Impact Factor (2014): 5.611}

Table 3: Efficacy of various plant extracts on rice leaf blast 7, 14 and 21 days in 2010 and 2011

\begin{tabular}{|c|c|c|c|c|}
\hline Plant extract & Day & 2010 & 2011 & Mean \\
\hline \multirow{3}{*}{ Aak } & 7 & 24.31 & 16.28 & 20.295 \\
\hline & 14 & 18.46 & 10.04 & 14.25 \\
\hline & 21 & 14.61 & 7.50 & 11.055 \\
\hline \multirow{3}{*}{ Ginger } & 7 & 17.23 & 20.32 & 18.775 \\
\hline & 14 & 10.68 & 16.62 & 13.65 \\
\hline & 21 & 8.19 & 11.45 & 9.82 \\
\hline \multirow{3}{*}{ Turmeric } & 7 & 26.40 & 23.07 & 24.735 \\
\hline & 14 & 20.23 & 17.03 & 18.63 \\
\hline & 21 & 17.27 & 13.28 & 15.275 \\
\hline \multirow{3}{*}{ Chilli } & 7 & 18.68 & 24.23 & 21.455 \\
\hline & 14 & 12.56 & 18.21 & 15.385 \\
\hline & 21 & 9.57 & 14.68 & 12.125 \\
\hline \multirow{3}{*}{ Datura } & 7 & 25.45 & 19.47 & 22.46 \\
\hline & 14 & 20.46 & 14.01 & 17.235 \\
\hline & 21 & 17.49 & 8.24 & 12.865 \\
\hline \multirow{3}{*}{ Garlic } & 7 & 20.43 & 16.39 & 18.41 \\
\hline & 14 & 16.29 & 8.73 & 12.51 \\
\hline & 21 & 12.54 & 7.24 & 9.89 \\
\hline \multirow{3}{*}{ Neem } & 7 & 22.24 & 23.33 & 22.785 \\
\hline & 14 & 18.36 & 17.38 & 17.87 \\
\hline & 21 & 14.33 & 15.24 & 14.785 \\
\hline \multirow{3}{*}{ Onion } & 7 & 21.40 & 19.24 & 20.32 \\
\hline & 14 & 17.24 & 13.19 & 15.215 \\
\hline & 21 & 13.45 & 10.21 & 11.83 \\
\hline \multirow{3}{*}{ Euclaputus } & 7 & 21.42 & 35.00 & 28.21 \\
\hline & 14 & 15.54 & 43.00 & 29.27 \\
\hline & 21 & 10.24 & 56.00 & 33.12 \\
\hline \multirow{3}{*}{ Control } & 7 & 36.37 & 29.28 & 32.825 \\
\hline & 14 & 44.33 & 35.48 & 39.905 \\
\hline & 21 & 55.52 & 47.23 & 51.375 \\
\hline
\end{tabular}

Table 4: Efficacy of various plant extracts on rice neck blast 7, 14 and 21 days in 2010 and 2011.

\begin{tabular}{|c|c|c|c|c|}
\hline Plant extract & Day & 2010 & 2011 & Mean \\
\hline \multirow{3}{*}{ Aak } & 7 & 22.51 & 21.45 & 21.98 \\
\hline & 14 & 16.45 & 17.44 & 16.945 \\
\hline & 21 & 11.42 & 12.45 & 11.935 \\
\hline \multirow{3}{*}{ Ginger } & 7 & 21.30 & 27.32 & 24.31 \\
\hline & 14 & 15.51 & 20.50 & 18.005 \\
\hline & 21 & 12.66 & 15.70 & 14.18 \\
\hline \multirow{3}{*}{ Turmeric } & 7 & 28.25 & 23.48 & 25.865 \\
\hline & 14 & 23.48 & 14.51 & 18.995 \\
\hline & 21 & 18.46 & 10.47 & 14.465 \\
\hline \multirow{3}{*}{ Chilli } & 7 & 18.27 & 23.60 & 20.935 \\
\hline & 14 & 13.58 & 15.32 & 14.45 \\
\hline & 21 & 10.45 & 11.40 & 10.925 \\
\hline \multirow{3}{*}{ Datura } & 7 & 23.63 & 27.48 & 25.555 \\
\hline & 14 & 17.45 & 24.66 & 21.055 \\
\hline & 21 & 13.54 & 20.46 & 17 \\
\hline \multirow{3}{*}{ Garlic } & 7 & 24.44 & 20.33 & 22.385 \\
\hline & 14 & 21.33 & 14.39 & 17.86 \\
\hline & 21 & 16.53 & 11.29 & 13.91 \\
\hline \multirow{3}{*}{ Neem } & 7 & 25.25 & 26.63 & 25.94 \\
\hline & 14 & 21.39 & 22.44 & 21.915 \\
\hline & 21 & 17.49 & 16.54 & 17.015 \\
\hline \multirow{3}{*}{ Onion } & 7 & 23.28 & 23.36 & 23.32 \\
\hline & 14 & 16.34 & 19.65 & 17.995 \\
\hline & 21 & 14.39 & 13.44 & 13.915 \\
\hline \multirow{3}{*}{ Euclaputus } & 7 & 20.47 & 36.47 & 28.47 \\
\hline & 14 & 15.50 & 45.68 & 30.59 \\
\hline & 21 & 10.29 & 58.63 & 34.46 \\
\hline \multirow{3}{*}{ Control } & 7 & 33.33 & 29.28 & 31.305 \\
\hline & 14 & 37.47 & 35.48 & 36.475 \\
\hline & 21 & 44.52 & 47.23 & 45.875 \\
\hline
\end{tabular}

Volume 5 Issue 1, January 2016 


\section{International Journal of Science and Research (IJSR) \\ ISSN (Online): 2319-7064}

Index Copernicus Value (2013): 6.14 | Impact Factor (2014): 5.611

\section{References}

[1] Luo, Y. P. S., Tang, N.G., Febellar, D.O. and TeBeest (1998) Risk analysis of yield losses caused by rice leaf blast associated with temperature changes above and below for five Asian countries. Agricultural Ecosystem and Environment 68:1970-205.

[2] Food and Agricultural Organization (FAO), 2000. Agriculture towards 2015/30. Technical Interim Report. April, 2000 Rome.

[3] Agrawal, M. and S.B. Agrawal (1989) Phytomonitoring of air pollution around a thermal power plant. Atomos. Environ.23:763 - 769

[4] Padmanabhan SY. 1965. Estimating losses from rice blast in India. Pages 203-221 in the rice blast disease. Proceeding of of symposium at IRRI July 1963. The Johns Hopkin Press Baltimore, Maryland.

[5] Teng PS. 1986. Crop losses appraisal in the tropics. Journal of Plant Protection 3, 39-50.

[6] Nuque FL, Bandong JM, Estrada BA, Lapis DB, Torres CQ. 1983. Common diseases of rice. 276-277 p. In: Rice production manual Philippines. University of Philippines, college Laguna, Philippines.

[7] Shafaullah, Khan, M. A., Khan, N. A., Salim-il-Yasin, \& Mahmood, Y. (2011). Response of rice germplasm to blast disease under field conditions. Pakistan Journal of Phytopathology, 23(1), 52-55.

[8] Khan, S. M., N. Javed, S. M. Khan and M.A. Gill. 2002. Screening of rice germplasm against blast disease caused by Pyricularia oryzaecav. In: National Conference of Plant Pathology, NARC, and Islamabad. Pp. 86-89

[9] Bateman, G. L., Ehle, H. and Wallace, H. A. H. (1986) Fungicidal treatment of cereals seeds. In: Seed treatment Jeffs(Ed) British Crop Protection Council Publications, Thornton Heath, pp 83-106.

[10] De Waard, S.K., Georgopoulos, S.G., Hollomon, D.W., Ishii, H., Leroux, P. N., Ragsdale, N. and Schwinn, F.J. (1993)Chemical control of plant diseases: problems and prospects. Annals of Reviews Phytopathology, 31: 403421.

[11] Mariappan, V., Rajeswari, E. and Kamalakannan, A.(1995) Management of rice blast, Pyriculariaoryzae by using neem (Azadirachtaindica) and other plant products. In: Mariappan, V. [Ed.] Neem for the Management of Crop Diseases. Associated Publishing Co., New Delhi, India, pp3-10.

[12] Choi, G. J., Jang, K. S., Kim, J. S., Lee, S. W., Cho, K. Y. \& Kim, J. C., (2004). In vivo fungal activity of 57 plant extracts against six plant pathogenic fungi. Plant Patholology Journal, 20:184-191.

[13] Netam, R.S., Bahadur, A.N., Tiwari, U. and Tiwari, R.K.S.(2011) Efficacy of plant extracts for the Control of (Pyricularia grisea) Blast of Rice under Field Condition of Bastar, Chhattisgarh. Research Journal of Agricultural Sciences, 2 (2): 269-271.

[14] Sing K.P., Singh K. (1983) Seed germination and seedling growth responses of some rice cultivars to water potentional treatments. Indian J. Plant Physiol. 26 (2): $182-188$

[15] Ghazanfar, M.U;Wakil, W.; Sahi S.T. and Saleem-ilYasin, (2009). Influence of various fungicides on the management of rice blast disease. Mycopath 7(1): 2934.

[16] Ansari M M. 1995. Indian Phytopathology 48: 268-270.

[17]IRRI 1996. Standard evaluation system for rice. 4th ed. IRRI, Manila, Phillipine. 